\title{
Debrecen légszennyezettségének vizsgálata epifiton zuzmók nehézfémtartalmának tanulmányozásával
}

\author{
Zs. SZABó1 ${ }^{1}$ A. KeCZÁnNÉ ÜvegES² \\ ${ }^{1}$ Debreceni Egyetem, Műsszaki Kar, Környezetmérnöki Tanszék, szofi0412@gmail.com \\ ${ }^{2}$ Debreceni Egyetem, Műszaki Kar, Környezetmérnöki Tanszék, auveges@eng.unideb.hu
}

Absztrakt. Kutatómunkánk során Debrecen város forgalmasabb csomópontjaiban vizsgáltuk a levegőminőséget nehézfém tartalom szempontjából. Vizsgálatainkhoz epifiton indikátornövényeket gyújtöttünk Debrecen meghatározott útszakaszai mentén, és városon kívüli kontrollterületen. A mintavétel a zuzmók vegetációs időszakának megfelelően március elején történt. A begyüjtött minták tisztítását, szárítását és roncsolását követően vizsgáltuk azok toxikus fémtartalmát Induktív Csatolású Plazma- Optikai Emissziós Spektrometria elven múködő készülékkel. Összesen 9 fém koncentrációját vizsgáltuk, többek között a nickel, ólom, réz és cink tartalmat.

\section{Bevezetés}

Városi környezetben - kivéve az iparvárosokat - a levegő minőség romlását főleg a közlekedésből és fütésből származó szennyezőanyagok befolyásolják, és ezek mellet nem hagyhatjuk figyelmen kívül a nehézfém mikroszennyezők jelenlétét. Az emberi tevékenység eredményeként keletkezett szennyező anyagok közül kiváltképp a gáz halmazállapotú anyagokkal kell foglalkozni, mert ezeknek a kiválasztásuk, semlegesítésük a legnehezebb [1] A toxikus elemek főleg a belsőégésű motorok kibocsátásából származtatható fémek az üzemanyag összetevőiből és égéstermékeiből, valamint az öregedő motor- és a katalizátor folyamataiból származnak. Magyarországon az 1990-es évek óta a benzin, mint motorhajtó anyag nem tartalmazhat ólom-tartalmú adalékanyagokat, így a motortérből nem, azonban a gépjárművekben található akkumlátorok révén emittálódhat a környezetbe. Króm jelenhet meg a kipufogógázban a belsőégésű motorokban használt - nemesfémeknél gazdaságosabb krómtartalmú katalizátorok elterjedése miatt [2]. A fékbetétek kopásából is emittálódnak szennyezők, ezeknek az összetétele változatos, de gyakran tartalmaznak antimont. A kopás során elsősorban rezet, nikkelt és krómot emittálnak, azonban kis mennyiségben az arzén, az ólom és policiklusos aromas szánhidrogének (PAH) is előfordulnak bennük [3.]. A gumiköpenyek kopásánál a kadmium az egyik legjelentősebb szennyezőanyag, amivel számolni kell. A kadmiumot stabilizáló adalékként keverik a gumiabroncsok anyagába, és az abroncs kopásával ez a nehézfém kikerül a környezetbe [4]. A másik meghatározó emittált elem a cink, ugyanis a vulkanizáláshoz ZnO-t használnak [5]. Az előbbiek mellett még a kenőolajok egy része is tartalmaz cinket és kadmiumot [6], de ezeken kívül még előfordulhat bennük réz és nikkel, de akár arzén valamint króm is.

A zuzmók bizonyos légszennyező anyagok indikátoraként alkalmazhatóak, mivel érzékenységük különböző légszennyező anyagokra nézve egyértelműen igazolható. Szenzibilitásuk alaki és 
morfológiai okokra vezethető vissza, valamint hogy a tápanyagot a levegőből és a vízből veszik fel. A vizsgált zuzmófajta a Phaeophyscia orbicularis, mely telepe lapos, vékony, szabálytalan alakú, színe kékes-szürke, nedvesítésre bezöldül. Jellemzően fák kérgein, ritkán kőzeteken található meg, terepi azonosítása egyszerű, valamint Debrecenben viszonylag sok helyen megtalálható.

\section{Anyag és módszer}

A vizsgálati minták Debrecen területén három nagyobb forgalmas útszakasz mentén, valamint az épített környezeten kívüli kontroll területről (Bükk-hegységből) kerültek begyüjtésre. Debrecenben az első mintaterület a Simonyi út és a Nagyerdei körút kereszteződésétől a Bem térig, a második szakasz a Nyíl utcától az Árpád térig, a harmadik a Rakovszky Dániel utca mentén a Faraktár utcai kereszteződésig tartott, ahol rendre 6 darab, 3 darab és 4 darab minta került begyüjtésre A teljes vizsgált útszakasz hossza közel 3 km hosszú. A mintavétel 2017. március 9-én történt.

A mintavétel fákról való zuzmógyüjtés volt, ami minden esetben a talajtól számítva 1 és 2 méter között történt, hogy a talajhoz közeli nitrogén dús mikrokörnyezet fajokra gyakorolt hatását kiküszöböljük. A növények fakéregről való eltávolítása műanyag késsel történt az esetleges fémszennyezés elkerülése miatt. A zuzmók felcímkézett, egyedi kóddal ellátott zárható műanyag tasakba kerültek. A minta előkészítésig minden minta hűtőben $+5^{\circ} \mathrm{C}$-on volt tárolva.

A minták hűtőből való kivétele után tömegmérésen estek át, majd háromszorosan desztillált vízzel történt gyors öblítés követően szárítószekrényben $105^{\circ} \mathrm{C}$-on 24 óra alatt lettek megszárítva. Az eszközök a keresztszennyeződés elkerülése miatt minden minta között el lettek öblítve háromszor desztillált vízzel készített 0,1 mol/dm3 koncentrációjú salétromsavas oldattal. A száraz minták ismételt tömegmérést („száraz” tömeg) követően inert, achát mozsárban lettek elporítva, majd a feltáráshoz szükséges 0,100-0,101 g mennyiségeket a bombákba mértük. A feltárás $3 \mathrm{ml}$ salétromsav illetve $1 \mathrm{ml}$ hidrogén-peroxid mellett ETHOS UP ultrahangos roncsoló készülékkel történt. A kapott oldatok analízis előtt szűrve lettek.

Az analízis induktív csatolású plazma - optikai emissziós spektrométerrel (ICP-OES) történt. A műszer fénykibocsátáson alapszik, miszerint vegyületeket, molekulákat gerjesztünk, és az általuk kibocsátott fény hullámhosszát, illetve intenzitását mérjük. Az előbbi a minőségi, az utóbbi pedig a mennyiségi elemzéshez szükséges.

\section{Eredmények értékelése}

Az ICP-OES készülékkel kapott eredményeket mg/kg egységben három tizedes jegyre kerekítve a zuzmók száraz tömegére vonatkoztatva az 1. táblázatban láthatóak. A minták színkódolva vannak, miszerint sárgával vannak jelölve a Simonyi úton (1-6 minta), kékkel a Nyíl utcán (7-9 minta), zölddel a Rakovszky Dániel utcán vett minták (10-13), valamint feketével a bükki kontroll minta (14). 


\begin{tabular}{|c|c|c|c|c|c|c|c|c|c|}
\hline $\begin{array}{c}\text { Minta } \\
\text { száma }\end{array}$ & $\begin{array}{c}\text { Arzén } \\
{[\mathbf{m g} / \mathbf{k g}]}\end{array}$ & $\begin{array}{c}\text { Kobalt } \\
{[\mathbf{m g} / \mathbf{k g}]}\end{array}$ & $\begin{array}{c}\text { Króm } \\
{[\mathbf{m g} / \mathbf{k g}]}\end{array}$ & $\begin{array}{c}\text { Réz } \\
{[\mathbf{m g} / \mathbf{k g}]}\end{array}$ & $\begin{array}{c}\text { Ólom } \\
{[\mathbf{m g} / \mathbf{k g}]}\end{array}$ & $\begin{array}{c}\text { Mangán } \\
{[\mathbf{m g} / \mathbf{k g}]}\end{array}$ & $\begin{array}{c}\text { Nikkel } \\
{[\mathbf{m g} / \mathbf{k g}]}\end{array}$ & $\begin{array}{c}\text { Cink } \\
{[\mathbf{m g} / \mathbf{k g}]}\end{array}$ & $\begin{array}{c}\text { Vanádium } \\
{[\mathrm{mg} / \mathbf{k g}]}\end{array}$ \\
\hline 1 & 3,068 & 0,623 & 11,762 & 27,191 & 13,854 & 55,225 & 3,500 & 70,993 & 6,328 \\
\hline 2 & 1,397 & 0,230 & 8,002 & 20,739 & 7,335 & 43,553 & 2,046 & 61,762 & 2,994 \\
\hline 3 & 2,427 & 0,379 & 8,299 & 34,641 & 9,660 & 51,621 & 2,282 & 64,375 & 3,981 \\
\hline 4 & 2,941 & 0,569 & 10,419 & 22,382 & 18,382 & 53,480 & 3,382 & 68,545 & 5,882 \\
\hline 5 & 1,843 & 0,272 & 9,154 & 19,360 & 9,360 & 51,765 & 2,376 & 54,710 & 3,104 \\
\hline 6 & 3,386 & 0,906 & 8,942 & 39,562 & 71,365 & 103,655 & 3,436 & 75,584 & 6,873 \\
\hline 7 & 3,375 & 0,733 & 8,320 & 16,307 & 11,716 & 65,468 & 2,170 & 79,360 & 6,268 \\
\hline 8 & 2,216 & 0,308 & 4,737 & 13,719 & 6,985 & 44,884 & 0,530 & 72,530 & 3,757 \\
\hline 9 & 3,415 & 0,829 & 7,646 & 31,532 & 46,88 & 145,112 & 2,488 & 78,786 & 6,439 \\
\hline 10 & 1,791 & 0,149 & 2,913 & 16,358 & 4,527 & 29,721 & 0,000 & 62,673 & 2,488 \\
\hline 11 & 2,495 & 0,403 & 5,996 & $\mathbf{2 2 , 8 5 0}$ & 11,564 & 43,954 & 1,296 & 61,992 & 5,374 \\
\hline 12 & 2,959 & 0,276 & 4,880 & 27,416 & 6,361 & 54,517 & 0,641 & 68,753 & 4,142 \\
\hline 13 & 4,453 & 0,794 & 8,904 & 39,013 & 10,503 & 83,117 & 2,178 & 88,476 & 6,873 \\
\hline 14 & 0,094 & 0,000 & 0,026 & 2,679 & 9,667 & 14,538 & 0,000 & 24,732 & 0,660 \\
\hline
\end{tabular}

1. táblázat: A minták toxikusfémtartalma három tizedesjegyre kerekítve.

Az 1. táblázat alapján látható, hogy a 13-as minta arzénkoncentrációja a legmagasabb $(4,453 \mathrm{mg} / \mathrm{kg})$, ami a Rakovszky Dániel és a Faraktár utcai kereszteződésben lett véve. Itt szinte állandóan nagy a forgalom, több autóbusz is jár erre, és a kereszteződésben a piros lámpánál folyamatosan állnak a feltorlódó jármúvek. Azonban a másik három forgalmi csomópontnál $(1,6,9)$ is magasak a mért értékek a kontroll mintához képest. Kobalt esetén a mért értékek nagyobb ingadozást mutatnak ( 0,15 mg/kg-tól 0,9 mg/kg-ig). A nagyobb forgalmi csomópontoknál vett 1-, 6-, 9- és 13-as minták kobalt koncentrációja kiemelkedően magas, rendre 0,623,0,906, 0,829 és 0,794 mg/kg értékeknek adódott, melyek az útvonal egyéb pontjaihoz képest 4-6 szoros mennyiségek, míg a vidéki háttér esetén (14) mennyisége a kimutatási határ alatt volt. Króm koncentrációk esetén megfigyelhetőek nagyobb kiugrások, melyek közül némelyik a forgalommal erősen terhelt forgalmi csomópontok környezetéből származott (1, 6 és 13 minta). Azonban az is megfigyelhető, hogy a sárga színnel kódolt minták mindegyike magas krómkoncentrációt mutatott, mely arra enged következtetni, hogy a $\mathrm{Cr}$ megnövekedett mennyiségéhez hozzájárulhat a vizsgált útszakasz villamosforgalma is. Réztartalmak kapcsán hasonló tendencia látható, mint az arzén esetén, a csomópontokból származó minták rézkoncentrációi (az 1. minta kivételével) kiemelkednek (39,562, 31,523 és 39,013 mg/kg a 6, 9 és 13as minták esetén), amelyek minimum 1,5 szeresei a vizsgált útszakasz többi részén mért eredményeknek. Az ólomnál mért értékek közül a 6-os minta kiemelkedően magas koncentrációjú (71,365 mg/kg). A 6-os minta a Bem térről származott, melyre jellemző az állandó nagy forgalom, a közlekedési lámpáknál várakozó autók sokasága, valamint a villamosforgalom, villamos megálló 
együttes jelenléte, ami tovább növeli a szennyezettség értékét. Érdekes módon a bükki mintában (14) nagyobb koncentráció figyelhető meg, mint pár városi mintában, ami valamilyen ólomszennyezésre enged következtetni a környéken. Mangán tekintetében a legmagasabb értékkel a 9-es minta rendelkezik $(145,112 \mathrm{mg} / \mathrm{kg})$, ami az Árpád téren lett gyüjtve. A másik három csomópont $(1,6,13)$ is magasabb koncentrációban tartalmaz Mn-t az útvonal többi pontján mért értékekhez képest. A nikkel értékeinél látható, hogy a kontroll területnél kimutatási határ alatti koncentrációkkal számolhatunk, illetve itt is hasonló tendencia mutatkozik, mint az előzőeknél, miszerint a nagyobb csomópontok értékei kimagaslóak a többihez képest. Megfigyelhető, hogy a vizsgált mikroelemek közül a cinknél kapott értékek nagyságrendileg nagyobbak. A vizsgált útszakasz tekintetében 54,710 mg/kg és 88,476 $\mathrm{mg} / \mathrm{kg}$ közötti cink halmozódott fel a zuzmókban, ami minden egyes eseten több, mint kétszerese a kontroll mintának $(24,732 \mathrm{mg} / \mathrm{kg})$.

\section{Összegzés}

Városi környezetben a levegő minőség romlásához nagyban hozzájárul a közlekedésből eredő szennyezőanyag kibocsátás. A közlekedésből származtatható kipufogógáz komponensek, mint primer szennyezőanyagok mellett (CO, NOx, VOC) számolnunk kell a szekunder szennyezőanyagok (03, aldehidek, PAN) légköri megjelenésével is. Mindezek mellett nem tekinthetünk el a közlekedésből származó toxikus fémek környezeti levegőben való megjelenésétől sem. Ezek vizsgálatához Debrecen forgalmasabb útszakaszai mentén Phaeophyscia orbicularis zuzmó mintákat gyűjtöttünk és ICP-OES készülékkel mértük azok toxikus fémtartalmát. A kapott eredmények alapján elmondható, hogy szinte az összes vizsgált elem koncentrációja hasonló tendenciát mutat, miszerint a nagy forgalmi csomópontokban $(1,6,9,13)$ a koncentrációk magasabbak, mint a vizsgált útvonal többi részén, $\mathrm{s}$ a legtöbb esetben a kontroll minta többszöröseinek adódtak. Ezek mellett a 4-es mintára is magasabb mért értékek jellemzőek, mint a szakasz többi részén, melyek között számottevő Cr szennyezés figyelhető meg, ami arra enged következtetni, hogy a villamosforgalom hozzájárul a környezeti toxikus fémszennyezéshez. A vizsgált elemek közül cink $(88,5 \mathrm{mg} / \mathrm{kg})$ és mangán $(145,1 \mathrm{mg} / \mathrm{kg})$ esetén mértük a legnagyobb koncentrációkat. Ólom tekintetében két kiugróan magas értéket mértünk: a 6-os mintában $(71,4 \mathrm{mg} / \mathrm{kg})$, és a 9-es mintában $(46,9 \mathrm{mg} / \mathrm{kg})$, ezen a két értéken kívül az útszakasz többi részén vett minták 6,4 mg/kg és 18,4 mg/kg közötti ólmot tartalmaztak. A Co eredmények alapján megfigyelhető, hogy a mért értékek nagyobb ingadozást mutatnak, azonban a forgalmi csomópontoknál kiemelkedően magas Co-koncentrációk adódtak $(0,623,0,906,0,829$ és 0,794 $\mathrm{mg} / \mathrm{kg}$ ), melyek az útvonal egyéb pontjai vett mintákhoz képest 4-6 szoros értékek. Összességében megállapítható, hogy az eredmények egységesen alátámasztják, hogy a nagy forgalmi csomópontok közelében vett zuzmóminták nagyobb mértékben szennyezettek, tehát nagyobb a szennyezőanyag kibocsátás, mint az út többi szakaszán.

\section{Hivatkozások}

[1] Beke J., Halász Gy., Kalmár T., Lengyel A., Peidl L., Szegedi A.,Vágvölgyi S. (2007), A környezetvédelem technikai alapjai I, Levegôtisztaság-védelem. Nyíregyházi Főiskola Bessenyei György Könyvkiadó, Nyíregyháza. 
[2] Balgord, W. D., (1973) Fine particles produces from automotive emissions-Control catalyst, Science 180, pp. 1168-1169.

[3] Westerlund C., Viklander M., Bäckström M. (2003) Seasonal variations in road runoff quality in Lulea, Sweden, Water Science and Technology 48 (9) pp.93-101.

[4] Harrison, R. M., Johnston, W. R. (1985) Deposition fluxes of lead, cadmium, copper and polynuclear aromatic hydrocarbons (PAH) on the verges of a major highway, The Science of the Total Environment, 46. pp. 121-135.

[5] Adachi, K., Tainosho, Y. (2004) Characterization of heavy metal particles embedded in tire dust, Environment International, 30. pp. 1009-1017.

[6] Ndiokwere, C. L. (1984) A study of heavy metal pollution from motor vehicle emissions and its effect on roadside soil, vegetation and crops in Nigeria, Environmental Pollution, 7 (1) pp. $35-42$. 